\title{
EDUKASI IBU MENYUSUI DENGAN ASI EKSKLUSIF MELALUI KOMUNIKASI INTERPERSONAL DI WILAYAH KERJA PAMULANG
}

\section{Health Teaching for Breasfeeding Mother with Exclusive Breastfeeding through Interpersonal Communication in Pamulang}

\author{
Desmawati $^{1}$, Agustina $^{2}$, Retno Dyah Kusumastuti ${ }^{3}$ \\ ${ }^{1}$ Departement Nurse-Midwifery, Nursing, Faculty of Health Science University of Pembangunan \\ Nasional Veteran Jakarta \\ ${ }^{2}$ Public Health, Faculty of University of Pembangunan Nasional Veteran Jakarta \\ ${ }^{3}$ Faculty of Social and Political Sciences University of Pembangunan Nasional Veteran Jakarta \\ *E-mail; desmawati@upnvj.ac.id
}

\begin{abstract}
ABSTRAK
Permasalahan pada ibu-ibu menyusui (busui) setelah melahirkan adalah mengalami ketidaklancaran pengeluaran ASI; tidak adanya produksi ASI, produksi ASI (payudaranya) penuh, namun ejeksi ASI tidak lancar, puting susu yang kurang menonjol, dan lain-lain sehingga masih banyak bayi yang diberikan Pengganti Air Susu Ibu (PASI), padahal makanan yang terbaik untuk bayi adalah ASI. Salah satu penyebab hal tersebut terjadi karena kurangnya pengetahuan ibu dan keluarga. Pengetahuan ibu menyusui dan keluarganya terkait ASI eksklusif sangat penting untuk memaksimalkan pemberian ASI eksklusif pada bayi. Selain itu ibu menyusui harus terhindar dari stress, cemas, ketidaknyamanan, ketidaktenangan atau ibu harus selalu bahagia. Tujuan dari pengabdian ini adalah menambah pengetahuan, meningkatkan pemahaman dan perubahan perilaku busui, dan keluarga di lingkungan wilayah kerja Puskesmas Pamulang sehingga cakupan pemberian ASI eksklusif meningkat. Metode yang digunakan adalah health teaching dan demontstrasi pada 12 busui dengan komunikasi interpersonal di Pamulang pada tahun 2018. Hasil yang didapat setelah diberikan health teaching adalah pengetahuan mereka meningkat setelah diberikan Pendidikan kesehatan. Kesimpulan bahwa health teaching bisa meningkatkan pengetahuan ibu menyusui tentang ASI eksklusif. Disarankan health teaching segera dilakukan setelah melahirkan pada ibu menyusui walaupun semasa hamil sudah pernah diberikan.
\end{abstract}

Kata kunci: Health teaching, Ibu menyusui, ASI eksklusif, komunikasi interpersonal

\section{ABSTRACT}

The problem for breatfeeding mothers after gave birth is there is no production of breast milk or obstacle in ejection of breast milk or flat nipples etc. Many babies are given a breast milk substitute. That is not good for the baby. The best food for the baby is breast milk because that contains the complement needed by the baby. This happens due to lack of knowledge of mother and their family, also lack of support from their family. Knowledge is important to facilitate breatfeeding mother for maximally exclusive breastfeeding. The purpose of this community service is to increase knowledge, skill, and change of behaviors of breastfeeding mother and their family. Method used the health teaching and demonstration with interpersonal communication. Results of this community service revealed that from 12 breastfeeding mothers who receving the health gteaching about exclusive breatfeeding make their breast milk smooth and increase their knowledge. Conclusion the health teaching can increase knowledge of breastfeeding mother after gave birth. The health teaching is suggested to give for breastfeeding mothe after gave birth, although already given during pregnancy. 
Key word: Health teaching, exclusive breastfeeding, breastfeeding mother, interpersonal communication

\section{PENDAHULUAN}

Wilayah Pamulang dan sekitarnya termasuk wilayah yang padat penduduk karena tempatnya strategis terletak di segitiga emas tiga provinsi; Banten, Jawa Barat, dan DKI Jakarta. Penduduk asli dan pendatang dari berbagai provinsi di Indonesia memadati wilayah ini, karena kebanyakan yang bekerja di ibukota negara tinggal di wilayah ini.

Begitu juga karakteristik penduduknya, wilayah ini banyak dalam usia subur. Pasangan usia subur akan berefek dengan banyaknya jumlah ibu melahirkan di Puskesmas Pamulang, rumah sakit, dan klinik-klinik bersalin diwilayah ini. Situasi dan kondisi ini membutuhkan tenaga kesehatan yang cukup memadai jumlahnya, namun kenyataan yang ada masih banyak tenaga kesehatan di wilayah ini beban kerjanya overload, contohnya Puskesmas pamulang, dengan kondisi dan situasi seperti ini bisa terbantu oleh mahasiswa/i keperawatan, kebidanan yang dinas atau praktek di tempat tersebut.

Oleh karenanya, tindakan keperawatan yang diberikan hanyalah yang berifat wajib atau harus yang diberikan kepada pasien. Sedangkan tidakan tambahan seperti pemberian edukasi hanya dilakukan jika sudah diminta dan diberikan saat ada waktu luang. Sementara untuk ASI eksklusif perlu diberikan lagi edukasinya sesegera mungkin setelah ibu melahirkan walaupun sudah diberikan semasa kehamilan.

Dari analisa situasi lapangan yang dilakukan tim pengabdian masyarakat di wilayah Pamulang sebagai mitra didapatkan pengetahuan ibu nifas-ibu menyusui dan keluarga mereka tentang ASI eksklusif masih kurang terutama bagi ibu primipara.

Tim pengabdi perlu menggiatkan untuk mengulang kembali pemberian edukasi ASI eksklusif di lingkungan wilayah kerja Pamulang setelah melahirkan walaupun sudah diberikan saat kehamilan karena kadangkala ibu dan keluarga sudah lupa atau perlu penegasan lagi dari tim kesehatan. Hal ini penting untuk menghindari terjadinya komplikasi atau efek tidak diberikannya ASI eksklusif pada bayi dan ibu seperti hiperbilirubin pada bayi, dan bisa membuat ibu demam meriang, sakit dipayudara, dan lainnya. Semua penyakit ini merupakan penyakit ketidaknyamanan yang secara umum merupakan masalah kesehatan masyarakat terutama ibu menyusui (busui) (Yohmi \& Rusli, 2008).

Kelancaran produksi

ASI dipengaruhi oleh banyak faktor seperti frekuensi pemberian ASI, berat bayi saat lahir, usia kehamilan saat bayi lahir, usia ibu dan paritas, stres dan penyakit akut, IMD, keberadaan perokok, konsumsi alkohol, perawatan payudara, penggunaan alat kontrasepsi, dan status gizi. Ketersediaan ASI yang lancar pada ibu menyusui akan membantu kesuksesan pemberian ASI eksklusif selama 6 bulan, sehingga membantu bayi tumbuh dan berkembang dengan baik sesuai rekomendasi dari WHO (Safitri, 2016). Selain itu, faktor yang mendominasi untuk ekelancaran ASI adalah isapan bayi (Tauriska \& Umamah, 2015), faktor lain posisi menyusui yang tepat, nyeri ringan, mobilisasi aktif, rooming in kontinu, dan pemberian intervensi areola-rolling massage 12 jampost sectio caesarea merupakan faktor penentu 
kecepatan pengeluaran ASI pada ibuibu post sectio caesarea (Desmawati, 2013).

Banyak penelitian yang sudah membuktikan bahwa massage pada tulang belakang busui bermanfaat untuk kelancara ASI busui, merangsang hormone prolactin dan oksitosin setelah melahirkan, sehingga disebut juga dengan pijat punggung (Yohmi \& Roesli, 2009). Pijat punggung belakang pada ibu post-partum menunjukkan dapat meningkatkan produksi dan ejeksi ASI dengan lancar (Desmawati, 2008). Pijat Mermet dan pijat oksitosin juga efektif untuk meningkatkan produksi ASI (Mardianingsih, Setyowati, Sabri, 2011).

Pemberian edukasi kembali tentang ASI eksklusif pada ibu post partum sesegera mungkin sudah didasari dengan evidence based penelitian yang banyak. Dari analisa situasi lapangan yang dilakukan tim pengabdian masyarakat ini didapatkan hampir lebih $50 \%$ ASI busui tidak keluar dengan lancar mulai dari 2 jam post-partum, pengetahuan busui dan keluarga tentang ASI eksklusif masih kurang, sedangkan teori mengatakan pengetahuan akan mempengaruhi sikap dan perilaku (Notoatdmodjo, 2010).

Pengabdian ini bertujuan meningkatkan pengetahuan ibu menyusui dan keluarga di wilayah kerja Pamulang, dan meningkatkan perubahan perilaku ibu menyusui.

Manfaat pengabdian ini membantu meningkatkan cakupan pemberian ASI eksklusif, ibu menyusui bisa memberikan ASI sedini mungkin setelah bayi lahir.

\section{METODE}

$\begin{array}{lcr}\text { Metode } & \text { dan teknik } & \text { dalam } \\ \text { menyampaikan } & \text { informasi } & \text { materi } \\ \text { penyuluhan } & \text { ini } & \text { akan } \\ \text { mempertimbangkan } & \text { semua } & \text { aspek }\end{array}$

holistic ibu menyusui (busui) sebagai penerima informasi yaitu sosial budaya, tempat, ruang dan waktu. Teknik yang digunakan adalah penyuluhan kelompok busui dan keluarga merupakan metoda paling efektif untuk menambah pengetahuan, mengubah sikap, pendapat atau perilaku seseorang, karena dengan pertemuan kelompok sesama busui dan didampingi keluarganya, mereka akan lebih terbuka, semangat dan saling memberikan dukungan satu sama lain yang sedang menghadapi masalah yang sama.

Secara teknis metode pelaksanaannya dibagi dalam beberapa tahap, yaitu :

Langkah-langkah dalam

pelaksanaan kegiatan;

Menyediakan bahan, tempat, media penyuluhan-demonstrasi:

a. Persiapan ruangan untuk tempat penyuluhan dan demonstrasi, persiapan media (LCD dan laptop).

b. Persiapan alat-alat untuk demonstrasi: kom berisi air hangat 2 pieces, termos berisi air hangat, bengkok, waslap 2 pieces, handuk 2 pieces, minyak kelapa original, kassa steril, tissue, kapas yang disiram air hangat (jangan alkohol), penampung ASI, bantal, kursi, air hangat putih minimal $200 \mathrm{ml}$, hammer, tensi meter, stetoskop, dan bantal sesuai kebutuhan dan kebutuhan lainnya

c. Persiapan ibu dan bayi beserta keluarganya, dan memberikan kuesioner kepada mereka untuk mengertahui pengethauan mereka sebelum dilakukan edukasi ulang post partum.

Pelaksaanaan dengan perkelompok, minimal 2 orang ibu menyusui dan bayi serta keluarganya supaya terjadi komunikasi interpersonal.

Setelah diberikan edukasi kepada ibu dan keluarga, maka pengabdi melakukan demonstrasi semua hal 
terkait ASI eksklusif seperti pemijatan bagaimana puting susu menonojol, bersih dan tidak lecet, nutrisi untuk meningkatkan produksi ASI, bagiamana posisi ibu dan bayi saat menyusui dalam meningkatkan ejeksi ASI, bagaimana ibu terhindar dari kecemasan, ketidaknyamanan, ketidaktenangan, dan lain-lain. Setelah itu pengabdi mememberikan kesempatan melakukan redemonstrasi oleh salah satu ibu menyusui:

Salah seorang ibu memperagakan halhal yang sudah diajarkan dengan dibantu keluarga serta berdiskusi dengan ibu-ibu lainnya.

Evaluasi penegtahuan ibu dan keluarga tentang ASI eksklusif dan pengeluaran ASI dilakukan sebelum ibu meninggalkan ruang perawatan nifas atau sebelum ibu pulang ke rumah (tidak lebih dari 24 jam pasca partum).

Evaluasi tahap lanjut dilakukan dengan memantau perilaku ibu menyusui di rumah dalam beberapa waktu kemudian (by phone)

\section{HASIL DAN PEMBAHASAN HASIL}

\section{Tabel 1}

Frekuensi dan persentase ibu menyusui berdasarkan data demografi $(n=12)$

\begin{tabular}{|c|c|c|}
\hline Karakteristik & $\begin{array}{l}\mathrm{Ya} \\
f(\%)\end{array}$ & $\begin{array}{l}\text { Tidak } \\
f(\%)\end{array}$ \\
\hline Usia [Mean] & \multicolumn{2}{|c|}{27.58} \\
\hline \multicolumn{3}{|l|}{ Level pendidikan } \\
\hline -Rendah (SD-SMP) & $3(25 \%)$ & $9(75 \%)$ \\
\hline -Tinggi (SMU-PT) & $9(75 \%)$ & $3(25 \%)$ \\
\hline Isapan bayi bagus & $12(100 \%)$ & $0(0 \%)$ \\
\hline $\begin{array}{l}\text { Anatomi payudara (puting) } \\
\text { menonjol normal }\end{array}$ & $12(100 \%)$ & $0(0 \%)$ \\
\hline Berat badan [Mean] & \multicolumn{2}{|c|}{60.58} \\
\hline
\end{tabular}

Tabel diatas menunjukkan usia rata-rata pada 12 orang menyusui adalah 27.58 tahun, rata-rata berpendidikan sekolah menengah atas dan perguruan tinggi, isapan bayi bagus, puting payudara menonjol normal, dan berat badan ibu rata-rata 60.58. Tidak ada faktor utama yang menghambat pengeluaran ASI secara dini.
ASI

\section{Pengetahuan ibu menyusui tentang}

eksklusif, produksi dan ejeksi ASI

Peningkatan pengetahuan ini sangat penting, dalam perubahan perilaku baik untuk melakukan usahausaha dalam meningkatkan produksi dan ejeksi ASI. Lebih jelas dapat dilihat pada tabel 2

Tabel 2

Distribusi pengetahuan busui tentang ASI eksklusif

Pengetahuan tentang :

Pengertian ASI eksklusif;

- Benar

- Salah

Manfaat ASI untuk bayi

$\begin{array}{llll}6 & 50 & 12 & 100\end{array}$

$\begin{array}{llll}6 & 50 & 0 & 0\end{array}$




$\begin{array}{lllll}\text {-Benar } & 6 & 50 & 12 & 100 \\ \text {-Salah } & 6 & 50 & 0 & 0 \\ \text { Manfaat menyusui bagi ibu } & & & & \\ \text {-Benar } & 4 & 33.33 & 12 & 100 \\ \text {-Salah } & 8 & 66.66 & 0 & 0 \\ \text { Makanan dan minuman meningkatkan ASI } & & & & \\ \text {-Benar } & 6 & 50 & 12 & 100 \\ \text {-Salah } & 6 & 50 & 0 & 0\end{array}$

Pengetahuan; perawatan payudara, posisi menyusui dll

\begin{tabular}{lllll}
-Benar & 2 & 16.66 & 12 & 100 \\
-Salah & 10 & 83.33 & 0 & 0 \\
Pengetahuan; menghindari stress, cemas, dll & & & & \\
-Benar & 2 & 16.66 & 12 & 100 \\
-Salah & 10 & 83.33 & 0 & 0 \\
\hline
\end{tabular}

Dapat dilihat perubahan peningkatan pengetahuan ibu menyusui tentang definisi ASI eksklusif, manfaat ASI untuk bayi dan ibu, makanan dan minuman yang bisa meningkatkan produksi ASI, serta pengetahuan ibu terkait posisi menyusui, perawatan puting dan payudara, cara mencegah stress meningkat setelah diberikan penyuhuan kesehatan denga komunikasi interpersonal.

\section{Tabel 3}

\section{Distribusi pengetahuan keluarga busui tentang ASI eksklusif}

\section{Pertanyaan pre-test post test}

jumlah $\%$ jumlah $\%$

\section{Pengetahuan tentang :}

Pengertian ASI eksklusif;

- Benar

- Salah

Manfaat ASI untuk bayi

-Benar

-Salah

$\begin{array}{llll}2 & 16.66 & 12 & 100 \\ 10 & 83.33 & 0 & 0 \\ 6 & 50 & 12 & 100 \\ 6 & 50 & 0 & 0\end{array}$

Manfaat menyusui bagi ibu

-Benar

-Salah

Makanan dan minuman meningkatkan ASI

-Benar

-Salah

$\begin{array}{llll}6 & 50 & 12 & 100 \\ 6 & 50 & 0 & 0\end{array}$

Pengetahuan; perawatan payudara, posisi menyusui dll

$\begin{array}{lllll}\text {-Benar } & 2 & 16.66 & 12 & 100 \\ \text {-Salah } & 10 & 83.33 & 0 & 0 \\ \text { Pengetahuan; menghindari stress, cemas, dll } & & & & \\ \text {-Benar } & 2 & 16.66 & 12 & 100 \\ \text {-Salah } & 10 & 83.33 & 0 & 0\end{array}$

Tabel 3 menunjukkan bahwa sebelum dilakukan edukasi ulang tentang ASI eksklusif 
pada ibu nifas hanya 2 keluarga $(16.66 \%)$ yang benar pernyataannya terkait definisi ASI eksklusif, sedangkan untuk pengetahuan terkait posisi menuyusui, perawatan putting dan payudara, dan lain- lain juga $16.66 \%$ yang bisa menjawab dengan benar.

Dapat dilihat perubahan peningkatan pengetahuan keluarga ibu menyusui tentang definisi ASI eksklusif, manfaat ASI untuk bayi dan ibu, makanan dan minuman yang bisa meningkatkan produksi ASI, serta pengetahuan ibu terkait posisi menyusui, perawatan puting dan payudara, cara mencegah stress meningkat setelah diberikan penyuluhuan kesehatan dengan komunikasi interpersonal.

Tampak ada perbedaan peningkatan pengetahuan ibu menyusui dan juga keluarga mereka setelah diberikan edukasi ulang setelah bayi lahir. Setelah diberikan penyuluhan dan demonstrasi >2 jam pasca-partum maka pengetahuan mereka meningkat (100\%).

\section{PEMBAHASAN}

Pada 12 orang ibu menyusui yang diberikan edukasi kesehatan pada pengabdian ini dilaporkan bahwa usia rata-rata 27.58 tahun, dengan berat badan rata-rata $60.58 \mathrm{~kg}, 75 \%$ bependidikan SMU dan perguruan tinggi, puting susu ibu normal menonjol, serta daya isap bayi bagus. Puting susu yang menonjol akan memudahkan bayi menyusu, bayi tidak mengalami kesulitan mengisap. Begitu juga jika isapan bayi benar maka akan menstimulasi hipotalamus yang akan merangsang kelenjar hipofise anterior menghasilkan hormon prolaktin dan hipofise posterior menghasilkan hormon oksitosin

Pengetahuan mereka meningkat setelah diberikan penyuluhan tentang ASI eksklusif (100\%). Dengan demonstrasi tentang perawatan putting, payudara, posisi menyusui, nutrisi, cara menghilangkan stress dan kecemasan, maka neurotransmitter akan merangsang medulla oblongata langsung mengirim pesan ke hypothalamus yang akan merangsang hipofise anterior menghasilkan hormone prolactin sehingga menyebabkan ASI diproduksi dan dengan merangsang kelenjer hypofise posterior untuk mengeluarkan hormone oksitosin. Oksitosin yang sampai pada alveoli akan mempengaruhi sel mioepitelium, kontraksi dari sel akan memeras air susu yang telah terbuat/diproduksi keluar dari alveoli dan masuk ke sistem duktulus yang untuk selanjutnya mengalir melalui duktus laktiferus masuk ke mulut bayi (Desmawati, 2010; Endah \& Masidinarsah, 2011).

Selain pengetahuan dan demonstrasi seputar tindakan usaha untuk meningkatkan produksi dan ejeksi ASI, faktor nutrisi dan cairan serta pikiran dan emosional ibu menyusui sangatlah memberi peranan penting dalam produksi dan ejeksi ASI. Makanan dan cairan yang masuk kedalam tubuh ibu sebagai bahan pembentukan ASI, jika seorang ibu menyusui mengkonsumsi makanan yang berigizi dan cairan yang cukup, maka bahan dasar pembentukan ASI sudah adekuat sehingga akan diproses tubuh dengan bantuan rolling massage dan emosional ibu yang stabil menghasilkan endorphin, encephalin, dan neurotransmitter akan merangsang medulla oblongata langsung mengirim pesan ke hypothalamus yang akan merangsang hipofise anterior menghasilkan hormone prolactin sehingga terbentuklah ASI serta tindakan rangsang oksitosin bisa merangsang kelenjer hypofise posterior untuk mengeluarkan hormone oksitosin yang apabila sampai pada alveoli akan mempengaruhi sel mioepitelium, mengejeksikan air susu yang sudah diproduksi keluar dari alveoli dan masuk ke sistem duktulus, mengalir melalui duktus laktiferus dan masuk ke mulut bayi dengan bantuan isapan bayi dan tekhnik menyusui yang benar (Desmawati, 2010; Desmawati, 2013). Faktor isapan bayi, puting susu yang menonjol, intervensi perawatan putting dan payudara, emosional ibu, dan tekhnik atau posisi ibu menyusui yang benar sangat mempengaruhi dalam membantu kelancaran pengeluaran ASI sedini mungkin.

Pengetahuan bertambah, ibu dan keluarga akan dengan semangat melakukan perubahan sikap dan perilaku demi memenuhi kebutuhan ASI sang buah hati. Keluarga yang 
pintar akan senantiasa memberikan motivasi kepada ibu yang sedang menyusui, sehingga kebutuhan psikologis ibu maksimal terpenuhi akan mempengaruhi produksi ASI.

\section{KESIMPULAN}

Pemberian edukasi tentang ASI eksklusif kembali segera setelah bayi lahir walaupun sudah diberika saat hamil, terbukti membantu meningkatkan pengetahuan ibu dan keluarga mereka, meningkatkan motivasi ibu dan keluarga dalam memberikan ASI untuk bayi. Kenyamanan psikologis, terhindar dari stress, kecemasa, ketidaktenangan meningkatkan produksi ASI dan ejeksi ASI pada ibu menyusui. Hal ini ditunjukkan dari setelah diberikan penyuluhan tentang ASI eksklusif terjadi peningkatan pengetahuan ibu menyusui tentang definisi ASI eksklusif, manfaat ASI buat bayi, makanan minuman yang bisa meningkatkan produksi ejeksi ASI, dan pengetahuan tentang semua intervensi seputar ASI. Semua ini terbukti meningkatkan produksi dan ejeksi ASI, karena merangsang oksitosin dan prolactin yang berperanan penting pembentukan dan penyaluran ASI keluar. Disarankan kepada ibu menyusui untuk melakukan mempraktekkan semua materi edukasi sehingga sukses dalam memebrikan ASI eksklusif kepada bayinya. Pengabdi menyarankan juga kepada keluarga untuk memberikan bantuan, dukungan kepada ibu, karena ibu dan bayi sangat membutuhkan support dari keluarga.

\section{DAFTAR PUSTAKA}

Desmawati (2010). Pengaruh areola massage \& rolling massage terhadap pengeluaran ASI secara dini pada ibu post partum normal. Bina Widya UPNVJ, 21(1), 1117.

Desmawati (2013). Faktor penentu kecepatan pengeluaran Air Susu pada Ibu Post Seksio Sesaria Jurnal Kesehatan masyarakat Nasional (Kesmas), 7(8), 360-364.
Desmawati (2014). Analisis faktor-faktor yang berhubungan dengan pemberian ASI eksklusif pada ibu bekerja. Bina Widya, 25(4), 168-172

Ekawati. H. (2016). Pengaruh rolling massage punggung terhadap peningkatan produksi ASI pada ibu nifas. Medical Technology and Public Health Journal (MTPH Journal). edisi 2016.

Endah, S. I., \& Masidinarsah, I. (2011). Pengaruh pijat oksitosin terhadap pengeluaran ASI kolostrum pada ibu post partum, Jurnal Kesehatan Kartika, 1-9.

Mardianingsih, E., Setyowati., \& Sabri,L. (2011).Efektifitas kombinasi teknik marmet dan pijat oksitosin terhadap produksi ASI. Jurnal Keperawatan Soedirman (The Soedirman Journal of Nursing), 6(1), 31-38

Notoatmodjo, S. (2010). Ilmu Perilaku Kesehatan. Jakarta: Rineka Cipta.

Riskesdas (2013). Badan Penelitian dan Pengembangan Kesehatan Kementerin Kesehatan RI Tahun 2013. Jakarta: Kemenkes RI

Safitri. I. (2016). Faktor-faktor yang mempengaruhi kelancaran produksi ASI pada ibu menyusui. Tesis: Universitas Muhammadiyah Surakarta.

Tauriska, T. A., \& Umamag. F. (2015). Hubungan antara isapan bayi dengan produksi ASI pada ibu menyusui. Journal of Health Sciences, 8(1); 15-21

WHO (2016). World Helath Statistics; Monitoring Health for the SDGs.

Yohmi, E., \& Roesli, U. (2008). Manajemen Laktasi. In: Ikatan Dokter Anak Indonesia. Bedah ASI. Jakarta: Balai penerbit FKUI, 17-3. 